\title{
6 House, Home, Health and Hygiene - Social Engineering of Workers in Elisabethville/ Lubumbashi (1940s to 1960s) Through the Lens of Language Usage
}

\section{Introduction}

After the foundation of Elisabethville (nowadays Lubumbashi) in 1910, one of the most important players in the mining sector in Katanga was the Union Minière $d u$ Haut-Katanga (UMHK). Especially after in the 1930s, the International Labor Organization (ILO) was putting pressure on the UMHK to abandon forced labor and the UMHK had to search for a solution to secure its high demand for a permanent workforce. The company's strategy was to implement a huge project of social engineering, including a new employment policy called "stabilization". To foster this new strategy, in 1925 the UMHK founded a specialized department, the Département Main d'Oeuvre Indigène. Besides the provision of schools, hospitals, leisure facilities and, of course, housing for UMHK workers, the company and its owner, the Belgian colonial state, relentlessly pursued their ideas of cleanliness and hygiene. Hygiene was immanently linked to health and both aspects were monitored by authorities at different levels. On a larger scale, the Belgians' concern for hygiene and health was visible in their policy of segregation in the city ${ }^{1}$ with different neighborhoods for the different city dwellers and a neutral zone (cordon sanitaire) in-between. ${ }^{2}$ On a smaller scale, the house became one of the core objects of the Belgians' concern for hygiene. The provided housing was therefore not only a tool of social engineering but - as the analyzed discourse on concrete measures reveals - a constant topic in debates often linked with concerns of health and hygiene. ${ }^{3}$

1 The segregation of a city was not a unique strategy of the Belgians but an approach taken also by the British and French colonial states.

2 See also Dibwe dia Mwembu in this publication.

3 For a discussion of the sanitation syndrome see e.g. Maynard W. Swanson, "The Sanitation Syndrome: Bubonic Plague and Urban Native Policy in the Cape Colony, 1900-1909," The Journal of African History 18, 3 (1977). 
The Belgian colonial state and the UMHK planned houses for the workers that reproduced the colonizers' ideas of family and home in every sense. The house and its interior design defined the ideal size of a family and the distribution of duties within the household. ${ }^{4}$ The worker's wife was supposed to secure a healthy and hygienic house to ascertain the productivity of the husband. She thus played a central role and became an addressee of the UMHK's different measures and channels of communication.

Writing about the ideal house for the staff of the colonial state in the Congo, Lagae $^{5}$ points out that:

$[\mathrm{H}]$ ygiene remained a key issue in the discussions on the colonial house in Congo throughout the colonial period. To a large extent, nor architects neither engineers but doctors controlled the debate. The central argument of the hygienist discourse on the colonial house was simple: healthy living conditions generate a good health, and thus increase the efficiency and working capacities of the colonial.

In this paper ${ }^{6}$ I will illustrate the UMHK's “civilizing” measures based on four interconnected topics (i.e. house, home, hygiene, and health) by analyzing the language usage through a variety of texts in which the respective authors argue for their specific position. By doing so, I put the discourse on these topics in focus. I follow Bendel-Larcher's definition of discourse. ${ }^{7}$ She states that discourse is a social process of understanding how to interpret and shape the world and that a discourse is modeled by the material reality (such as body painting, clothes, architecture or urban planning) and therefore takes effect on it through social practices. Discourse manifests itself in concrete texts that represent the knowledge and reasoning of a particular time. If we want to investigate why

4 For a discussion on the definition of social engineering see Etzemüller (2010). He hints at the organization of space as one of the central domains of social engineering (he refers e.g. to Ebenezer Howard's plan of the garden city) and specifies that city planners not only planned on larger scales (e.g. cities) but also on smaller ratios such as an apartment or a house. He discusses the example of a "functional" apartment, where spatial segregation prevents undesirable behavior, such as the blending of areas for sleeping, cooking and personal hygiene. Mixing these spatial domains was considered problematic from an ethical and hygienic viewpoint. Thomas Etzemüller, "Social Engineering, Version: 1:0," Docupedia-Zeitgeschichte (11.2.2010): 7-8, accessed November 20, 2018.

5 Johan Lagae, "In Search of a 'comme chez soi.' The Ideal Colonial House in Congo, 1885-1960,” in Itinéraires croisés de la modernité Congo belge, 1920-1950, ed. Jean-Luc Vellut (Paris \& Tervuren: L’Harmattan, 2001), 242.

6 This paper was written within the scope of the Austrian Science Fund granted project "Employment-tied Housing in (post)colonial Africa" (Project no. P29566-G28, Department of African Studies, University of Vienna). For further information see: housing.univie.ac.at 7 Sylvia Bendel-Larcher, Linguistische Diskursanalyse (Tübingen: Narr, 2015), 16. 
certain ideologies prevail at a given time, we must first reveal the ideological background based on texts. ${ }^{8}$ Texts, of course, contain several topics. In my contribution, I will highlight parts of texts that approach the same topic(s). The fragments of discourse that share a topic are threads of a discourse. The discourse level is the social locus from where a statement is made (in spoken or written form). These levels are closely intertwined with the discourse position, a term that refers to the ideological locus of the speaking person, group or medium.

In my analysis, I aim to reveal the perceptions of house, home, health, and hygiene via its discursive realization to gain a better understanding about the discourse positions of the actors involved in the process of social engineering. All involved actors (the colonial state, the company, but also the workers) participated in the negotiation processes on what was relevant at a specific moment in time.

For this paper, the textural cores (i.e. material reality) for my analysis are, firstly, official publications of the Belgian colonial state such as $\grave{A}$ chacun sa maison. ${ }^{9}$ Such publications offer an insight into the ideologies prevalent at the time of Belgium's colonial policy that formed the basis for the UMHK's strategies and decisions. Therefore, the second source of texts is from the company: the company-owned journal Mwana Shaba ${ }^{10}$ and the minutes of different of $\mathrm{UMHK}^{11}$ board meetings from the corresponding years.

Communication, including negotiation processes, was based on the very trivial fact that those communicating needed to make sure that they would be understood. The choice of French was obvious for UMHK minutes, as these

8 For a comprehensive overview on discourse analysis see e.g. Bendel-Larcher, Linguistische Diskursanalyse. Siegfried Jäger, Kritische Diskursanalyse: Eine Einführung (Münster: Unrast, 2012), 80, 83. Walter Schicho, "Diskursanalyse" in Qualitative Methoden in der Entwicklungsforschung, ed. Petra Dannecker and Birgit Englert (Wien: Mandelbaum, 2014), 135.

9 Editions du Bureau de l'Information pour Indigènes (INFIND), Service des A.I.M.O. du Gouvernement Général, À chacun sa maison (Kalina, 1953).

10 Accessed at the Library of Contemporary History in the Royal Museum for Central Africa, Tervuren, Belgium. Mwana Shaba is the Swahili term to describe a copper worker and, as the journal's name reveals, the potential readers were the workers of UMHK's copper mines. This journal contains information about the company, pages for distraction, riddles, information on lifestyle, reports about other countries, letters to the editors, information about the political situation etc. Mwana Shaba was published on a monthly basis and was written in French and Swahili. The journal reached a readership of approximately 28,000 workers, plus respective family members living in the same household.

11 In the state archives in Brussels, Archives générales du Royaume 2 - Dépôt Joseph Cuvelier, the minutes of the different boards are available, from the foundation of UMHK in 1906 until the company became Gécamines in 1966 and later UMICORE. 
documents were intended for internal use and communication with the metropolis Brussels. ${ }^{12}$ But French was - in combination with Swahili - also the language chosen for publications of the Belgian colonial state such as À chacun sa maison.

Even though in primary education the colonial authorities generally gave preference to the use of African rather than European languages, they promoted French ${ }^{13}$ with regard to "secondary education [which] was always, and in all locations, organized around French as the sole medium of instruction, except in most technical schools and in teacher training schools."14 The colonial state could therefore proceed from the assumption that the Congolese readership had proficiency in French; moreover, Meeuwis describes how the Congolese demanded education in French, as they did not want to be inhibited from upward social mobility by a language barrier. However, the workers of the mines were not necessarily highly proficient in their colonizers' language, as not all of them received formal education. Moreover, workers were recruited from diverse regions of the Congo and thus brought their different languages to Elisabethville. Swahili (the language also strongly promoted by the missionaries) represented the lingua franca in the mining camps and later became the first language in the region. ${ }^{15}$

The languages used in Mwana Shaba were French and - to a lesser degree Swahili. The editors often advertised information bilingually as will be shown further below. The UMHK's language policy for Mwana Shaba reflects their wish to be understood - hence, their choice of Swahili - but also their aim to educate their workers. Also, in the minutes of the meetings of the Department of the UMHK Service d'Afrique, ${ }^{16}$ it was explicitly stated that French and Swahili should be used for Mwana Shaba.

12 For a comprehensive overview of the Belgians' controversial subject of the role of Dutch and French in the metropolis, but also in the colony, see Michael Meeuwis, "Bilingual Inequality: Linguistic Rights and Disenfranchisement in Late Belgian Colonization,” Journal of Pragmatics 43 (2011).

13 Meeuwis, "Bilingual Inequality."

14 Meeuwis, "Bilingual Inequality," 1280.

15 Aurélia Ferrari, Marcel Kalunga and Georges Mulumbwa, Le Swahili de Lubumbashi (Paris: Karthala, 2014), 107. Daniela Waldburger, "Swahili in Eastern Congo: Status, Role and Attitudes," in Pluricentric Languages and Non-Dominant Varieties Worldwide, ed. Rudolf Muhr (Frankfurt am Main; Bern; Bruxelles; New York; Oxford; Warszawa; Wien: Peter Lang, 2016), 149.

16 Rapport Annuel 1959, Union Minière du Haut-Katanga - Services d'Afrique, Département M.O.I., AGR 2, n658, 57. 
In the following, I will first provide some background information on the (urban) history of Lubumbashi (Elisabethville) and the UMHK in order to then discuss the UMHK's mission of social engineering by illustrating the themes of house, home, health and hygiene based on the above-mentioned text types that were produced by the involved actors. The colonial endeavor of social engineering is thus looked at through the lens of linguistic representation of power strategies. I argue that the Belgian colonial state and the UMHK acted on the basis of paternalism to control and stabilize the workforce. The provision of housing was one of their means of surveillance. The company's decisions in favor of specific house types and of the disposition of interior design were discussed from a technical perspective, but they deceitfully imposed an ideologically biased understanding of domesticity on the workers and their families.

\section{Lubumbashi (Former Elisabethville) and the Union Minière du Haut-Katanga}

Elisabethville was founded in 1910 by the Belgian Government two years after it had taken over the colony from King Leopold II. ${ }^{17}$ Belgium chose this location because of its geo-political importance. The Belgian Government wanted to control the British influence from Northern Rhodesia and South Africa which went hand-in-glove with the railroad construction in the region. The railroad became Katanga's first and main link to the outside world until the late 1920s. ${ }^{18}$ The site was chosen because of its proximity to the already existing copper mine of Etoile du Congo and the copper-ore smelting oven installed by the UMHK on the nearby Lubumbashi River but also to keep an eye on the English-speaking Europeans who were already developing mines as well the railroad in the Copperbelt. ${ }^{19}$

The first European quarter of Elisabethville was planned as early as 1910 . One year later, an African quarter was formed, but it lay separate from the European quarter with a distance of 170 meters. This so-called zone neutre was

17 For a comprehensive overview of the history of Elisabethville see e.g. Bruce Fetter, The Creation of Elisabethville, 1910-1940 (Stanford: Hoover Institution Press, 1976).

18 Johan Lagae and Sofie Boonen, "A City Constructed by 'des gens d'ailleurs': Urban Development and Migration Policies in Colonial Lubumbashi, 1910-1930,” Comparativ: Zeitschrift für Globalgeschichte und vergleichende Gesellschaftsforschung 25, no. 4 (2015): 52. 19 Fetter, The Creation of Elisabethville, 3. 
not unique for Elisabethville but typical for colonial urban planning elsewhere and reflected the colonial state's concerns of sanitation and hygiene. ${ }^{20}$

In the center of the mining area in Katanga, one of the most significant players was the UMHK. This company was founded in 1906 and for about 100 years, it was the most important mining company of the Congo. Hence, the history of the UMHK and the history of Lubumbashi/Elisabethville were closely linked, as the following quote also illustrates:

[T] he town lived according to the rhythm of the Union Minière/Gecamines which regulated the lives of its personnel from birth to death: the company housed and fed them, sent missions to the country side to seek spouses for the worker, educated their children, planned their leisure and so on. (Dibwe 2001) A proverb stated that 'the Union Minière [or alternatively: salaried work] is the father and the mother' (Union Minière [kaji] njo baba, njo mama). ${ }^{21}$

The city and work were inseparable, as Dibwe dia Mwembu describes. ${ }^{22} \mathrm{He}$ stresses that in order to stay in Elisabethville (and later Lubumbashi) ${ }^{23}$ a person needed a contract of employment. The formal sector reigned supreme. The informal was excluded, absent or pretended to be unknown. Work had deeply influenced the urban mentality, and the public image of the city even influenced the neighboring territory of Northern Rhodesia in a positive manner.

To maintain a profitable mining sector, the UMHK not only needed to recruit but also to accommodate a rapidly increasing number of workers. The company did so by creating workers' camps for bachelors in close proximity to their mines

20 Lagae and Boonen, “A City Constructed by 'des gens d'ailleurs', 56-57. For Lubumbashi in the 1920s Lagae states: "While both hospitals were erected outside the grid of the ville européenne, the hospital for Africans was located within the so-called zone neutre, the cordon sanitaire introduced in the early 1920s as a buffer zone between the ville européenne and the first native town, the commune Kamalondo. [...] The hospital for the white community was built on the opposite side, at the largest possible distance from where lived the majority of the native population.” Johan Lagae, “Towards a Rough Guide for Lubumbashi, Congo: Rethinking 'shared built heritage' in a former Belgian colony,” http://bk.home.tudelft.nl/fileadmin/ Faculteit/BK/Actueel/Symposia_en_congressen/African_Perpectives/Programme/African_ Architectures/doc/APD_wp_5_lagae_paper.pdf, accessed July 3, 2018.

21 Pierre Petit and Georges Mulumbwa Mutambwa, “'LA CRISE': Lexicon and the Ethos of the Second Economy in Lubumbashi," Africa 75, no. 4 (2005): 470.

22 Donatien Dibwe dia Mwembu, "Lubumbashi: histoire et mémoire d'une ville industrielle," in Villes d'Afrique: explorations en histoire urbaines, ed. Jean-Luc Vellut (Paris: L'Harmattan, 2007), 138.

23 In 1966, the city's name was changed from Elisabethville to Lubumbashi. 
in the early years. But very soon, the UMHK also started to build houses for workers and their families. On 9 December 1941, the mining workers in Elisabethville went on strike as a culmination point of a longer wave of protest. ${ }^{24}$ Their main goal was to demand higher wages to meet rising living costs. While the workers assembled, the situation got out of control and at least 20 workers died. The strike and the subsequent uncertainty took place in the middle of the Second World War when the copper industry crucially mattered as a backbone of Belgium's economic strength. At that time the stabilization of workforce was highly important to the UMHK: "The strike wave of 1941 clearly shows that the around 17,000 workers were not content with the working and living conditions in Union Minière's mines and compounds. The company portrayed itself as a considerate employer and displayed photos and films of smiling workers, clean hospitals, and happy families." 25 It is against this backdrop that the project of social engineering started.

\section{Social Engineering and Stabilization}

The project of social engineering was played out by the UMHK on different layers. Not only were the work and the housing situation of workers controlled but equally so education or leisure activities. In 1956, the UMHK produced a series of films celebrating its fiftieth anniversary. One of these films, entitled En Cinquante $A n s^{26}$ (In 50 Years), portrayed the workers' lives, the benefits of being an UMHK employee, however, not work itself. The housing facilities provided were displayed, as well as all the advantages from healthcare to courses offered to workers and their wives. One particular scene portrayed a family sitting around a table in their home. A tablecloth protected the table, some

24 For further details see e.g. Donatien Dibwe dia Mwembu, Histoire des conditions de vie de travailleurs de l'Union Mininère du Haut-Katanga/Gécamines (1910-1999) (Lubumbashi: Presses universitaires de Lubumbashi, 2001). Julia Seibert, “'Wind of Change’: Worker's Unrest and the Transformation of Colonial Capital in Katanga - Belgian Congo," in Work and Culture in a Globalized World: From Africa to Latin America, ed. Babacar Fall, Ineke PhafRheinberger and Andreas Eckert (Berlin \& Paris: Karthala, 2015).

Julia Seibert, In die globale Wirtschaft gezwungen: Arbeit und kolonialer Kapitalismus im Kongo (1885-1960) (Frankfurt: Campus, 2016).

25 Seibert, "Wind of Change," 263.

26 En Cinquante Ans, accessed June 23, 2018, https://www.youtube.com/watch?v= 9z4GtyCvlCg\&sns=em. 
flowers were arranged in the middle, the head of the family was sitting at the end of the table, and all members of the family were gathered to enjoy the meal with fork and knife. They enjoyed the food cooked by the wife and were combining the best of what in the film is called the "art" of European cuisine with the "traditional" cuisine. Not only the workers but also the workers' wives were supposed to attend different types of courses, from childcare to shoe shining. The UMHK covered all possible aspects of life and conditioned the workers and their families according to the Belgian ideal of middle-class life. Typical Sundays were accurately described to be very similar to the Sundays in Europe with going for a walk and meeting friends. The scene ended with a shot of a table outside in the garden with several persons sitting around a table that was covered by a tablecloth and glasses perfectly laid out on the table. Using the medium of film, the UMHK made propaganda not only for the workplace but also for the very life they offered their workers, thereby presenting the company's perception of a family life. At its very center were the house and domesticity.

The UMHK tried to stabilize the workforce by ensuring that workers stayed healthy and were emotionally balanced. The film mentions that 80 percent of the workers then (1956) were married. A married man was considered to be even-tempered and taken well care of. Hunt points out that the Belgian authorities as well as missionaries were concerned about the demographic pattern in their colony, with men outnumbering women. ${ }^{27}$ Therefore, the hint in the film to the nearly balanced ratio between men and women shows the UMHK's awareness of this topic and their pride of the achieved demographic pattern.

The alleged balanced ratio between men and women in workers' camps as presented in the film differed from the situation outside the camps. In the camps, married women were presented to have a stronger position especially compared to the unmarried women in the city where "[c]olonial commentators thought women in the cities were floundering, disoriented, vulnerable, and corruptible due to idleness, excessive leisure, and a void of custom. The notion that the moral authority of customary culture did not extend to urban centers was ubiquitous in Belgian colonial discourse."28

Moreover, the UMHK was fighting against customary culture and especially tried to suppress bigamy, as the annual reports of the Département Main d'Oeuvre

27 Nancy Rose Hunt, “Domesticity and Colonialism in Belgian Africa: Usumbura's Foyer Social, 1946-1960,” Signs: Journal of Women in Culture and Society 15, no. 31 (1990): 451.

28 Hunt, "Domesticity and Colonialism in Belgian Africa," 451. 
Indigène reveal. A section on parasitism appeared each year. In 1948, for instance, the UMHK stated that they would continue to fight against bigamy: ${ }^{29}$

Nous avons continué notre campagne contre la bigamie et divers cas spéciaux montrant à quels résultats peut conduire la bigamie ont été exposés aux C.I.E. Certains travailleurs ont encore essayé de prendre en défaut notre vigilance. Il existe certainement encore dans nos camps des cas de bigamie, déjà anciens, contre lesquels la réaction sera plus difficile et où, actuellement, la seule attitude possible est d'ignorer la seconde femme. Ce n'est que petit à petit, par une inlassable propagande éducative que nous pourrons définitivement éliminer ces situations anormales. Il faut aussi espérer que le Gouvernement donnera suite au voeu[sic] exprimé par le Conseil de Gouvernement - Session 1948 - de voir interdire progressivement la polygamie dans les centres extra-coutumiers. ${ }^{30}$
We continued our campaign against bigamy, and various special cases showing to which results bigamy can lead were exposed to C.I.E. Some workers have again tried to defect our vigilance. There are certainly still cases of bigamy in our camps, old ones, against which the reaction will be more difficult and where, at present, the only possible attitude is to ignore the second woman. It is only little by little, by a tireless educational propaganda that we can once for all eliminate these abnormal situations. It is also hoped that the Government will respond to the wish expressed by the Governing Council - Session 1948 - to progressively ban polygamy in extracustomary centers.

Bigamy is described with the adjective "abnormal." The UMHK's concern had thus an ethical background, as the existence of several wives was not in line with the idea of the nuclear family, but bigamy also constituted a financial problem. Workers acknowledged the - according to Europeans' perspective - illegitimate children and demanded the same rights with respect to housing, education, and food rations, for these children and their mothers as they were granted for the official wife and children. In the annual report of 1947, the UMHK's financial concerns were explicitly verbalized: "Enfin, au moment où des charges sociales de plus en plus lourdes viennent grever le budget des employeurs de main d'oeuvre indigène, il importe que soit nettement défini le Statut de la famille indigène."31

The UMHK's decisions and strategies in the project of social engineering mirrored the Belgian colonial state's ideas of development for the colony. In 1949, the Belgian colonial Government introduced a 10-year plan for the

29 Rapport Annuel 1948, Union Minière du Haut-Katanga - Services d'Afrique, Département M.O.I., AGR 2, n654-03043, 18.

30 All translations are by the author.

31 "Finally, when increasingly heavy social charges are burdening the budget of employers of native labor, it is important that the status of the indigenous family is clearly defined." Rapport Annuel 1947, Union Minière du Haut-Katanga - Services d'Afrique, Département M.O.I., AGR 2, nº54-03042, 21. 
economic and social development of the Congo, ${ }^{32}$ which included important infrastructure projects, such as public buildings and housing facilities for the Congolese. ${ }^{33}$ One of the proposed plans was the so-called Système Grévisse. Ferdinand Grévisse was a district officer of that time who published a study about so-called "native quarters" in Lubumbashi. In his view, Africans should be motivated to build the houses themselves, of course under strict supervision and under consideration of a long list of constraints. ${ }^{34}$ The idea of the Système Grévisse was that the colonial state builds the foundation to ensure the right size and exact location of the house on a parcel of land, but that its future inhabitants should build the houses themselves from the material provided by the government at a good price. Ideally, this would minimize the costs, as no construction company was involved and many pre-fabricated parts such as windows, doors, and roofs would be used. For Grévisse ${ }^{35}$ himself, the social component was equally important. He argued that such a scheme would lead to the stabilization of the lives of urban Africans and it would be easier to incorporate them in the colonial administration. ${ }^{36}$ The director of human resources of the Département Main d'Oeuvre Indigène, Dr. L. Mottoule, defined the company's stabilization policy in 1946 as "l'emploi de tous les moyens normaux propres à amener le travailleur noir à aimer le travail et à y rester attaché le plus long possible." 37 The policy included a number of measures aimed at binding the workers to the UMHK in the long term. ${ }^{38}$ Brausch points out that the stabilization was successful: "This paternalistic policy, which so irritates the champions of social freedom, produced nevertheless a remarkable stabilisation of labour and encouraged the establishment of workers' settlements with a fairly good demographic equilibrium." 39

32 Ministère des Colonies, Plan décennal pour le Développement économique et social du Congo belge (Brussels: Editions de Visscher, 1949).

33 Johan Lagae, "Modern Living in the Congo: The 1958 Colonial Housing Exhibit and Postwar Domestic Practices in the Belgian Colony," The Journal of Architecture 9, no. 4 (2004): 479.

34 Alice Chapelier, Elisabethville - essai de géographie urbaine (Brussels, 1957), 47-49, 65.

35 Ferdinand Grévisse, Le Centre Extra-Coutumier d'Elisabethville: quelques aspects de la politique indigène du Haut-Katanga industriel (Brussels: Institut Royal Colonial Belge, 1951).

36 See also Boonen and Lagae in this publication.

37 "The use of all the normal means necessary to bring the black worker to love the work and to remain attached to it as long as possible.” L. Mottoule, Politique sociale de l'Union Minière du Haut-Katanga pour sa main d'oeuvre indigène (Brussels, 1946). Citation in: Union Minière du Haut Katanga 1906-1956, N.N., (1956), 242.

38 Seibert, "Wind of Change," 261.

39 Georges Brausch, Belgian Administration in the Congo (Oxford: Oxford University Press, 1961), 13. 
The stabilization came at the price of a constant surveillance of the UMHK workers. As pointed out in Mwana Shaba, ${ }^{40}$ workers were requested to always carry the plastic identity and working card with their picture, which was a document that indicated the workplace and job title of the worker, and a family register booklet. Mwana Shaba published this notification in French and Swahili to ensure that everybody would understand the ordinance.

As work was the element linking the colonial state, the UMHK and the employees, it is worth looking at the perception of the concept of work. Dibwe dia Mwembu discusses three different stages of a temporal perception of work ( $k a z i$ in Swahili) by workers of which the second is relevant for the time focus of this paper. While approximately up to the 1940s kazi was considered slavery, after World War II the perception of kazi gained a very positive connotation equaling kazi ni maisha mzuri (work means a good life). ${ }^{41}$ This experience of having a good life was due to the appreciation workers experienced when the UMHK needed their workforce and thus provided them with rich social services and amenities. Fabian discusses the meaning of the word kazi (work) on a semantic level:

In Katanga Swahili the noun kazi may cover a wide range of activities, moods, attitudes, and attributes. [...] In some expressions a specific denotation may be due to idiomatic usage, e.g. in the often heard kaziyako "that's your business, it's up to you, go to hell." It may also be achieved through a context-specific contrast such as in the opposition between furaha and kazi [...]. But the overwhelming majority of expressions in which kazi has a specified meaning is based on complexes formed with the connective particle $\{a\}$, especially those which function as characterizations. These may signify a trade or profession: kazi ya mwalimu "being a teacher;" a type of employment: kazi ya Union Minière "being employed by the Union Minière;" a degree of exertion, effort: kazi ya nguvu "hard work." Similarly we find that most verbal expressions are complex, combining a verb with the noun kazi and often adding further specifications through the connective \{a\}. Examples are kufanya kazi ya chauffeur or kutumika kazi ya chauffeur "to work as a driver." 42

Why is the perception relevant here? I argue that, when focusing on the analyzed time period, work was experienced as the source of a good life, that the house was one, if not the central, element of this experience of the good life. The life of a worker was defined by work itself, while the status of the position was relevant for the allocation of housing in general, and the type of house in

40 Mwana Shaba, no. 123, 15 April 1966, 15.

41 Donatien Dibwe dia Mwembu, "La Perception du kazi (travail salarié) par les travailleurs de la Gécamines (1910-2010),” in La Société congolaise face à la modernité (1700-2010): mélanges eurafricains offerts à Jean-Luc Vellut, ed. Mathieu Zana Etambala and Pamphile Mabiala Mantuba-Ngoma (Paris \& Tervuren: L'Harmattan, 2017), 163-167.

42 Johannes Fabian, "Kazi: Conceptualizations of Labor in a Charismatic Movement among Swahili-Speaking Workers,” Cahiers d'études africaines 13, no. 50 (1973): 304-305. 
particular. In the "slavery" phase of work, housing for workers basically was a shelter and workers were housed in poor conditions. However, after the Second World War, work was more and more linked to reputation and social security, and this materialized in the house itself. Moreover, the house offered many possibilities to shape the everyday life of Congolese workers and their families. In other words, the house (i.e. the home) was a main target for social engineering. In the following, I will extract fragments of discourse in some publications by the UMHK and the Belgian government, which refer to house, home, health, and hygiene to demonstrate the linguistic strategies of persuasion of workers by the UMHK and the Belgian government.

\section{Voices of the Belgian Colonial State and the UMHK}

\section{Paternalism}

Against the backdrop of the 10-year plan for the development of the Congo, let us first have a look at the publication À chacun sa maison first published in 1953. The Belgian colonial state's Office for the Information of the Native People published and distributed this brochure for free. It was written in order to motivate the Congolese to build their houses along the lines of Grévisse's philosophy.

The preface of the brochure explicitly stated that, "nous avons voulu aider le plus grand nombre d'entre vous à faire de ce rêve une réalité." 43 The "we" was the Belgian colonial state while the "you" were the Congolese. This opposition of "we", the Belgians, and "you", the Congolese, was often combined with the paternalistic approach of the Belgians, like in the following sentence which also appeared in the preface:

Nous exprimons le souhait que, si vous lisez aujourd'hui cette brochure sous un toit étranger, vous ayez dans quelques mois le plaisir de la relire confortablement installé dans la maison attrayante que le conseils et instructions données plus loin vous auront permis de bâtir.
We express the wish that, if you read this brochure today under a foreign roof, you will have the pleasure of rereading it in a few months comfortably installed in the nice house that the advices and instructions given later will have allowed you to build.

With this wording the Congolese were not attributed an active role; they were presented as beneficiaries of the colonial state's welfare. Jean Jadot, a well-known engineer working for the Belgian colonial state, explicitly referred to the welfare

43 "We wanted to help as many of you as possible make this dream become true." 
thought as follows: "N'oublions jamais que la seule justification de notre action coloniale, c'est le bien que nous faisons aux populations indigènes."44

Also, Grévisse used the paternalistic style when he pointed to the urgency of achieving hygienic standards to protect the population from consequences of poor hygiene and cited a medical report:

Dès la fin de 1912 se posent à la cité indigène de très sérieux problèmes d'hygiène. Les habitants se ravitaillent en eau dans un dembo. Cette eau est polluée par les baigneurs, les lavandières et les animaux divaguant. A ce moment, un premier rapport médical souligne l'urgente nécessité de prendre des mesures pour protéger 'la population si cruellement décimée jusqu'à présent.'
As early as the end of 1912, the native city faced a very serious problems of hygiene. The inhabitants refuel water in a dembo. This water is polluted by swimmers, washing women and wandering animals. Right now, a first medical report underlines the urgent need to take measures to protect 'the population so cruelly decimated so far.'

But not only the Belgian colonial state but also the UMHK positioned the workers in the same beneficiary role and, in addition, often criticized them. As shown above, this occurred in the company's campaign against parasitism. The voice of the UMHK is available through the administrative and technocratic language style in the minutes of the different kind of board meetings. As far as workers' demands are concerned, they were (only) presented in form of a bullet list, without comments, which therefore does not reveal anything about the company's point of view on those demands. The company's mindset regarding the workers becomes visible in the comments on evening courses for the workers. In the annual report of 1950, the courses for general education were introduced as following: ${ }^{45}$

Donne aux illettrés et semi-lettrés l'occasion d'augmenter leur bagage en lecture Kiswahili, calcul, dessin, et notions de français parlé. Prépare aux Cours de Perfectionnement Professionnel. Fonctionne régulièrement dans certains sièges, moins bien dans d'autres. Le Noir ne considère que l'intérêt immédiat. Sa grande ambition est de connaître le français, signe extérieur de civilisation. Calcul, mesure, dessin, langue maternelle, lui semblent superflus.
Give the illiterate and semi-literate an opportunity to increase their proficiency in reading Kiswahili, calculation, drawing, and notions of spoken French. Prepare for professional development courses. Work regularly in some places, less well in others. The black considers only the immediate interest. His great ambition is to know French, an outward sign of civilization. Calculation, measurement, drawing, mother tongue, seem superfluous to him.

44 "Let us never forget that the only justification for our colonial action is the good we are doing to the native people." Citation in: André-Bernard Ergo, Congo Belge - La colonie assassinée (Paris: L’Harmattan, 2009), preface.

45 Rapport Annuel 1950, Union Miniére du Haut-Katanga - Services d'Afrique, Département M.O.I., AGR 2, nº55-03046. 


\section{On House, Home, Health and Hygiene}

With the following sentence, readers were introduced to $\grave{A}$ chacun sa maison:

Qui n'a rêvé d'être propriétaire d'une jolie maison, d'avoir à soi un vrai foyer où se retrouvent chaque jour l'époux dévoué, la femme aimante et de beaux enfants pleins de santé? (emphasis added)

\begin{abstract}
Who is not dreaming of being the owner of a nice house, having a real home where every day a self-sacrificing wife, the loving woman and handsome healthy children are waiting?
\end{abstract}

The introduction to this brochure, dedicated to technical aspects on how to construct houses, started with a presentation of the house, which was characterized as being the place of the "real home." What was presented was the idea of what a home should be, rather than the house as a materialized object itself. Home and house were thus discursively linked. ${ }^{46}$ In addition, children were described as healthy, and health and hygiene were closely connected as will be presented later.

The brochure burst with advice which was visually identifiable by boxes, with capital letters. Young, newly wed husbands were also among the potential readers:

JEUNE MARIE! N'oublie jamais, en choisissant le plan de ta maison, que tu es appelé à devenir père d'une famille peut-être nombreuse. Il est moins coûteux de construire grand dès le début que faire des agrandissements plus tard! (15)
YOUNG HUSBAND! Never forget, by choosing the plan of your house, you are encouraged to become the father of a potentially large family. It is less costly build big from the beginning than to make enlargements later!

This idea of a home and the provision of sufficient space for all members of the family was repeated over and over in similar words and phrases. The Belgian colonial state's concern for enough space for the family - as it becomes clearer in a section about the ventilation of the house - was not linked with their idea of comfort for the inhabitants but rather with the concern for hygiene. What the "neutral zone" was for the city, "sufficient space" was for the house. Hygiene was thus one of the main fragments in the discourse on house and home, not only in this brochure but also for the colonial state. The discourse fragments of technical and constructional aspects of the interior were not only linked with

46 In Swahili the expression for "at home" nyumbani stems from the noun for "house", nyumba, which gets a locative-suffix - ni. In Swahili therefore, there is no lexical difference of "at/in the house" and "home". 
questions of domesticity but also with the colonizers' ideas to control hygiene and health.

The idea of the so-called evolution was another aspect prominently featured in the publication. The introduction of the brochure offered an overview of the Belgians' assumption about the history of the house in the Congo and opened with a reference to what the Belgians considered the simplest form of a traditional Congolese house. A picture of a cave illustrated what was described as not comfortable. ${ }^{47}$ Several pages were then dedicated to the different types of houses. It was a demonstration of the evolution of housing types with increasing influence by European houses. Finally, the ideal house for a Congolese was presented under the name maison de pisé influencée par l'architecture européenne ${ }^{48}$ (clay house influenced by European architecture). The house was praised for being appealing and the reader learnt that adding some changes to the traditional house would be sufficient so that - without investing a lot more money - the house would become plus saine et plus agréable (a healthier and more pleasant home). Again, a box with bold and capital letters concluded this section and referred to health:

\section{CIVILISATION implique MAISONS SAINES ET CIVILIZATION implies HEALTHY AND CONFORTABLES \\ COMFORTABLE HOUSES}

47 In "Vocabulary of Elisabethville" Yav describes the housing situation of domestic servants in the years after King Leopold's death. In contrast to the Belgians' assumptions (Congolese are happy with caves etc.), the domestic servants in Elisabethville complained early about the unsuitable housing situation offered by their employers. For instance, "as far as sleeping goes they failed us by building for us those outhouses which have remained the same up to now.", "They were big trouble, those many Whites when they lived in Termite Hills [Termite Hills was the first white settlement in Elisabethville, DW]. Then we boys lived in true misery.", "Because they thought [it good] to build for the black man just a one-room-house. [But] this man had his wife and his children some of them male, some of them female. When he goes to work, the poor boy, when he wakes up, he says to all his grown-up children: Mothers and fathers, you must excuse me. Get up and leave, or go first outside. Me, your old man, I want to put on my clothes first. Truly, then the man's children began to file out, out of respect because their father wanted to get dressed so he could go to work.", "And should this White man have two rooms, enough to give both to his employee, the boy, he puts a lock on it [to make it] his chicken coop or rabbit hutch." Johannes Fabian, History from Below: The "Vocabulary of Elisabethville" by André Yav, Text, Translations, and Interpretive Essay (Amsterdam \& Philadelphia: John Benjamins, 1990), 71, 75.

48 "Mais l'existence des habitants des cavernes ne devait guère être confortable, comme le laisse supposer la photo ci-dessous.”, 5. Editions du Bureau de l'Information pour Indigénes (INFIND), Service des A.I.M.O. du Gouvernement Général, À chacun sa maison (Kalina, 1953), 5. 
Another publication which gave significant importance to the concept of health and hygiene was the UMHK's journal Mwana Shaba. In that sense, the persuasive intention of the company to socially engineer the workers remained a continuous feature in the colonial as well as the postcolonial era. ${ }^{49}$

In an article from 1967, Mwana Shaba ${ }^{50}$ offered a brief outline of workers' housing in Lubumbashi. Photographs showing the old and new refurbished houses illustrated the text. This article appeared when the shortage of housing had again become a serious problem. An interview with Mr. Mulunda, head of the Housing Service Department, complemented the descriptive part of the text. The voice was given to an individual explaining the measures that were taken to improve the situation. He answered the question of his interviewer who wanted to know about the used materials for the new houses for the workers:

Elles répondent toutes aux exigences de l'hygiène et du confort. Dans les nouveaux quartiers, vous trouverez toutes les maisons pourvues de distribution d'eau, d'une douche et de l'éclairage électrique. [.. .] Avec un peu de persévérance, les travailleurs peuvent aménager un jardin coquet et bien fleuri.
They all meet the requirements of hygiene and comfort. In the new neighborhoods, you will find all houses provided with water supply, a bathroom and electric lighting. [...] With a little endurance, workers can develop a pretty flower garden.

Once again, the focus lays explicitly on hygiene (and comfort), with explanations of what that meant in terms of technical equipment. Evidently, the editors did not take it for granted that workers generally showed enough effort, otherwise they would not have added this complement. Workers were constantly assessed as unable to anticipate.

But already years before, in 1949, in the annual report of UMHK's Département Main d'Oeuvre Indigène the company had expressed its lack of understanding that workers did not possess "le mobilier que l'on pourrait raisonnablement s'attendre à trouver chez eux."51 The company stressed that workers would indeed have had enough money and that the situation could only be explained by the workers' lack of discipline:

49 By 1966 Gécamines was the successor to the UMHK and by then a state-controlled company, but Mwana Shaba was still published.

50 Mwana Shaba, no. 147, 15 October 1967, 2-4.

51 "Furniture that we could reasonably expect to find at home.” Rapport Annuel 1949, Union Minière du Haut-Katanga - Services d'Afrique, Département M.O.I., AGR 2, nº55-03045, 23. 
Nous ne pouvons, pour expliquer cet état de choses, que répéter les raisons que nous invoquions dans notre Rapport de 1948, c'est à dire notre refus de vendre à crédit et l'imprévoyance di noir qui ne sait pas s'imposer la discipline de l'économie. Nous sommes cependant tentés d'y ajouter l'influence du jeu et l'abus des boissons qui prennent de plus en plus d'extension.
To explain this situation, we can only repeat the reasons we invoked in our 1948 report, that is, our refusal grant credit [to buy the furniture] and the improvidence of the black who is unable to show thrifty discipline. We are, however, tempted to add the influence of gambling and the abuse of drinks that are becoming more and more extensive.

The company linked the alleged lack of discipline in financial issues with a lack of discipline in other domains, such as the lack of willingness to buy adequate furniture. The worker was presented as attracted by gambling and alcohol - two leisure activities that led to spending money in the presumedly wrong way. Hence, the lack of discipline was discursively linked with the lack of furniture, the materialized object of what constituted a home. A year later, furniture was again an issue mentioned in the annual report. The UMHK had tried to sell simple and cheap furniture to the workers but failed: ${ }^{52}$

Le Département a renoncé à intervenir pour procurer aux travailleurs, du mobilier simple et peu coûteux. Cette initiative n'a pas rencontré le succès qu'on attendait. Il se confirme que l'amélioration du confort dont s'entoure le travailleur, ne peut résulter que d'une lente mais persistante action éducative.
The Department has refrained from intervening to provide workers with simple and inexpensive furniture. This initiative did not meet the expected success. It seems that the improvement of the comfort of which the worker surrounds himself can only result from a slow but persistent educational action.

Interestingly though, in the annual report from 1960, the members of the Département Main d'Oeuvre Indigène explicitly claimed that the company should sell furniture to workers. ${ }^{53}$ Furniture was a recurring topic throughout the years without significant changes regarding the point of views of the company or the workers. The UMHK tried to sell furniture, stopped again, tried again, while workers expressed their concerns as regards prices that were considered too high. In the end, the UMHK had the workers pegged as lacking financial discipline.

52 Rapport Annuel 1950, Union Minière du Haut-Katanga - Services d'Afrique, Département M.O.I., AGR 2, nº55-03046, 12.

53 Rapport Annuel 1960, Union Minière du Haut-Katanga - Services d'Afrique, Département M.O.I., AGR 2, nº36, 88. 
Another topic with which housing was discursively linked was technical facets. In the annual report of 1947, the UMHK uttered a very brief idea of the ideal family home under the section "housing" which usually discussed more technical issues: ${ }^{54}$

Des logements de 2, 3 et même 4 pièces sont réservés aux familles nombreuses. Outre les pièces d'habitation proprement dites, il existe une cuisine. Les derniers types de logement, adoptés en 1946, sont conçu de telle façon qu'on pourra plus tard y ajouter un "livingroom" spacieux, doté d'une cuisinière en fonte où la ménagère pourra préparer les repas en saison froide, la cuisine se faisant en saison chaude dans une annexe, le fournil de chez nous. Si on obtient, grâce à ce living où se réunira la famille, que la femme y prépare les repas, $y$ vive avec son mari et ses enfants et, dernière mais difficile étape, que les repas y soient pris en commun, un pas énorme sera réalisé vers l'évolution de la femme indigène et la constitution de familles suivant la conception européenne.
Houses of 2, 3 or even 4 rooms are reserved for big families. If not mentioned otherwise, there exists a kitchen. The latest type of houses (adopted in 1946) were planned so that one can later add a spacious living-room, equipped with a cooking range made of cast iron where the housewife can prepare the meals in the cold season, while in the warm season meals are prepared in an annex [. . .]. If, thanks to this living room, we achieve that the family sits together, that the woman prepares the meals there, that she lives there together with her husband and their children, and - the last and most difficult step - that the meals are partaken of together, then a huge step for the evolution of the native woman as well as the constitution of the family according to the European concept will be realized.

Like in the above discussed brochure, $A$ chacun sa maison, the house - in this case the kitchen and the living room - was not only referred to in technical terms. These two rooms represented the location of an idea, namely the Europeans' ideology of the ideal family and the role of the woman as the responsible one for the preparation of the meals to be shared in the living room. The kitchen and the living room served as a place to project ideas of social engineering. The ideal home was the place where the worker ideally spent his leisure time with his wife and children, with furniture he was able to afford because he withdrew from gambling and drinking alcohol.

Mwana Shaba also had a section dedicated to le vrai savoir vivre (the real art of living). Workers were able to read about lifestyle questions such as how to eat with a fork and knife or new technologies, such as how to make or receive a phone call and the corresponding social behavior. Under the section Votre Page Madame (Your Page Madam), a section dedicated to the wives of the

54 Rapport Annuel 1947, Union Minière du Haut-Katanga - Services d'Afrique, Département M.O.I., AGR 2, n654-03042, 29. 
workers, a picture of a flower arrangement was introduced by the following words: ${ }^{55}$

Garnissez votre intérieur, rendez-le accueillant. Fleurissez-le, et votre mari, le soir, sera heureux après sa journée de travail de retrouver son beau foyer, et d'y rester...
Garnish your interior, make it welcoming. adore it with flowers, and in the evening your husband will be happy after his day's work to find his beautiful home, and stay there ...

The flower bouquet was not only presented as a home decoration but first and foremost as a tool for emphasizing after-work domesticity of the husband. The imperative form chosen to address the housewife further attributed to her the power and responsibility to help condition a productive worker. Flower arrangements in the Belgian Congo were promoted by missionaries' ideas of domesticity ${ }^{56}$ and were later popularized by foyers sociaux (social homes) which were "Belgian domestic training institutions for African women, founded for married women living in colonial urban centers. Some women were learning to cook, mend, iron, and wash clothes, and how to wean their infants and decorate their homes, and a selected few were being trained to work (for pay) as auxiliary aids or monitors in the classroom." ${ }^{57}$ Thus, workers were useful to the colony as labor force, while women were ensuring the reproduction of the labor force. ${ }^{58}$ The knowledge of household tasks such as arranging flowers was therefore only one of the many reflections of colonial attempts of social engineering of the Congolese. ${ }^{59}$

Votre page madame offered a wide variety of topics considered important for women by the editors, from ideas about hairstyle to the importance of handbags or recipes for the loving husband. These "civilizing" ideas of how a woman should be and of how she should behave were often linked - to the UMHK's idea of hygiene, from proper nails for proper women to the proper way of childcare. Another example within the same domain of hygiene and health referred to the big cleaning of the house (le grand nettoyage) which was published in the very

55 Mwana Shaba, no. 13, Dec. 1964.

56 See Hunt, "Domesticity and Colonialism in Belgian Africa." Nancy Rose Hunt, A Colonial Lexicon of Birth Ritual, Medicalization, and Mobility in the Congo (Durham, NC: Duke University Press, 1999), 83, 153, 249, 254; Peter Lambertz, Seekers and Things: Spiritual Movements and Aesthetic Difference in Kinshasa (Oxford/New York: Berghahn, 2018), 99.

57 Hunt, "Domesticity and Colonialism in Belgian Africa," 447.

58 Hunt, "Domesticity and Colonialism in Belgian Africa," 451.

59 Lambertz points out in Chapter 3 of his monograph that flower arrangements were a totally new concept for the Congolese. Flowers were associated with plants and plants were used for traditional medicine and not as a decorative object. Lambertz, Peter. Seekers and Things: Spiritual Movements and Aesthetic Difference in Kinshasa. Oxford and New York: Berghahn, 2018. 
first issue of Mwana Shaba in 1965. In a highly detailed manner, every step of a big cleaning was described. Readers learnt, for instance, that the woman was expected to make use of a wet cleaning rag, know how to scrub the clothes and many more details. As a term, however, "the big cleaning" also referred to general suggestions. It was deemed inappropriate if children slept in dirty clothes. They were supposed to be clean and to sleep in a clean bed. Moreover, it was lectured that insects must either not enter a house or be relentlessly dispelled. The article ended with the notification that UMHK's service d'hygiène would regularly enter the house to disinfect the rooms. Insects, more particularly anopheles mosquitos, represented not only a threat to an individual's health but constituted a major threat to the productivity of the UMHK worker.

\section{Voices of UMHK's Workers}

In 1947, the UMHK established the Conseil indigène d'entreprise whose members were selected by the workers themselves. The company listened to the demands and suggestions of these members, as these representatives of the workers attended the company meetings.

The annual reports of the UMHK's Département Main d'Oeuvre Indigène reveal the company's view on housing issues in many subcategories linked to the workforce, such as numbers of workers, legal aspects, pension schemes, infrastructure, the organization of leisure activities, housing etc. Among the topics discussed and recorded in writing are also the lists of demands by the Conseil indigène d'entreprise directed at the company. As these demands were written down by a member of this board, they do not represent the direct voices of the workers but at least offer an understanding of the workers' concerns and opinions.

In the following, the claims by the members of the Conseil indigène d'entreprise, as reported in the annual reports from 1947 to $1965,{ }^{60}$ shall illustrate that the demands were very diverse; they illustrate the link between house, home, health, and hygiene and that the house was part of the infrastructure provided. The workers expressed, among other things, concerns that schools were progressively closed, a path to have access to the cemetery, permission of mothers to stay with a child who is hospitalized, a bicycles parking area close to the

60 See primary sources: Rapports Annuels 1947-1965, Union Minière du Haut-Katanga Services d'Afrique, Département M.O.I., AGR 2. 
workplace, the reopening of the canteens in the Cité, ${ }^{61}$ signs for toilets in the Cité indicating femmes (women) and hommes (men) etc. Most demands by the workers in the minutes of these annual reports touched on themes linked to work, health issues (e.g. hospitals), social activities and, more generally, the life in the Cité as well as the services provided - from food distribution to films projected during the movie nights and pension schemes.

The workers' demands related (besides work issues themselves, such as working hours, safety regulations etc.) to houses as well as the infrastructural environment. One category around which the demands concentrated was the provision of electricity. Electrification was generally urgently demanded and, over the years, dissatisfied workers repeatedly demanded electric light in each room of the house. Some of the requests were very detailed and included the wish for quicker replacement of broken electric bulbs or an increase of the hours with illumination. Another issue raised concerning infrastructure was water. On the one hand, workers demanded that the company distributed water containers to the houses, while on the other hand they explicitly expressed their desire to have running water in all houses. Equally, the shortage of water was repeatedly raised, as was the bad quality of water or problems with water pressure. Furthermore, health, hygiene, and disinfection were equally important to the workers. They asked for the distribution of disinfectant or a better quality of the insect control drugs. The provision of litter bins was likewise claimed.

As regards the houses, the toilet, a basic object linked to hygiene, was a topic of permanent request, as the council kept raising the demand for provision of toilets in all houses. Individual toilets, showers and sinks were requested as well as the fact that toilets should adjoin the houses. Other issues linked to the house concerned the demand for floors made of concrete (including in the old houses), the repair of houses, a wooden balcony and a cusinière bantoue (i.e. a simpler charcoal stove), more wood for cooking and heating or sinks situated also outside the house. Generally, the council claimed access to bigger and more modern houses during several years, with a special emphasis on bigger houses for big families and/or houses with bigger windows and interior doors. The doors represent by far the most frequently discussed subject matter among the house-related complaints. Workers requested the installation of interior doors in the houses during several years or asked that the process of the installation of the interior doors should be speeded up. Other laments referred to the quality and the type of doors. Requests for specific doors were

61 The term Cité refers to the area in Elisabethville where workers were accommodated by the UMHK. 
doors to separate the dining room from the living room, dividing walls between shower and toilet or to have a second exterior door. Other physical structure related requests also popped up, such as the size and quality of windows or the quality of the paint and chalk used for the interior; workers equally asked for a projecting roof to store charcoal and new or renovated kitchens.

The main concerns remained the same over many years: water, electricity, and doors. Repeated requests for doors that could be locked from the inside might allude to the workers' need to gain some privacy. The workers' concerns also increasingly reflected health and hygiene issues, as mosquito nets, disinfection drugs, and the waste problem started becoming topics. Starting as of the 1960s, the demands changed and were more frequently linked with their wish for more comfort, like having more rooms, getting more modern kitchens, and services such as public phones nearby.

This long list of demands by the workers is the only information we can filter out of the annual reports about their concerns, even though, as mentioned above, the demands were minuted by the UMHK. There are no sources that reveal how the negotiation process actually unfolded, how the members of Conseil indigène d'entreprise argued for their claims or the counterarguments the company put forward. While the UMHK's viewpoints in the discussion with the Conseil indigène d'entreprise were sometimes well documented, the workers' ideological locus was silenced, as their voice is reduced to a bullet list of technical topics in the annual reports.

\section{Conclusions}

The UMHK's policy of stabilization was a way to control all aspects of the workers' lives from birth to death. The company took care of housing for the workers, provided food, health care, leisure activities etc. The UMHK and the Belgian colonial state conditioned the workers in every sense. As has been shown above, the Belgian colonial state and the UMHK acted with a paternalistic attitude that intruded on nearly every domain of the workers' everyday life. The paternalistic approach is manifested in the constant "othering" of the Congolese. The UMHK saw its "other" - the workers - mainly as beneficiaries in need of guidance. In addition, publications by the UMHK (like Mwana Shaba or the issues mentioned in the annual reports) and by the Belgians presupposed that the Congolese needed to be educated or that they lacked discipline. The provision of housing was one of UMHK's major means of surveillance. 
The ideological locus of the Belgian colonial state and the UMHK is identifiable in the topics and the fragments of discourse they chose to combine in their discussion on housing issues. Not only in official state propaganda publications but also in annual reports by the UMHK, the discourse fragment of "house" (i.e. the material provided) was constantly coupled with several other fragments which equally intersect: firstly, with "home" as the location of domesticity, the place of wife and children; secondly, with "health" as a standard to be ensured in the house, guaranteeing that the husband stayed a profitable employee (the family's health was, for the same reasons, likewise important); thirdly, with "hygiene" as the basis for health which became an issue of general importance.

The ideological locus of the workers cannot be identified, but based on the topics they submitted, we do at least get an idea of their concerns and demands as has been shown on the basis of the minutes of the UMHK meetings with the Conseil indigène d'entreprise. Against this backdrop, it can be assessed that the workers' notion of a healthy and hygienic house largely corresponded with the social notions and cultural paradigms of the Belgian colonial state and the UMHK. Workers' requests did not differ from what workers would have requested in the metropolis. Smaller differences, such as the demand for the "Bantu kitchen", might have existed.

As has been discussed, the Belgians and the UMHK linked the concept of the house to their policy of social engineering. Thus, the Belgian colonial state's advice for the construction of houses, along with the UMHK's arguments and decisions for specific types of houses, as well as other issues regarding workers' housing, did not merely represent a discourse on technical measures - even though interior design, for instance, was discussed in technical terms (e.g. the ideal location of the stove in the kitchen). The technical discourse imposed the Belgian colonial state's and the UMHK's ideologically biased understanding of domesticity on the workers and their families.

\section{References}

\section{Archival Sources}

State archives in Brussels, Belgium, Archives générales du Royaume 2 - Dépôt Joseph Cuvelier, Première série (AGR 2)

№634 Union Minière du Haut-Katanga - Services d’Afrique, Département M.O.I.: Rapport Annuel, 1958.

N635 Union Minière du Haut-Katanga - Services d’Afrique, Département M.O.I.: Rapport Annuel, 1959. 
N636 Union Minière du Haut-Katanga - Services d’Afrique, Département M.O.I.: Rapport Annuel, 1960.

Nº637 Union Minière du Haut-Katanga - Services d’Afrique, Département M.O.I.: Rapport Annuel, 1961.

Nº38 Union Minière du Haut-Katanga - Services d’Afrique, Département M.O.I.: Rapport Annuel, 1962.

Nº639 Union Minière du Haut-Katanga - Services d’Afrique, Département M.O.I.: Rapport Annuel, 1963.

N640 Union Minière du Haut-Katanga - Services d’Afrique, Département M.O.I.: Rapport Annuel, 1964.

Nº54-03042 Union Minière du Haut-Katanga - Services d'Afrique, Département M.O.I.: Rapport Annuel, 1947.

N654-03043 Union Minière du Haut-Katanga - Services d’Afrique, Département M.O.I.: Rapport Annuel, 1948.

N655-03045 Union Minière du Haut-Katanga - Services d’Afrique, Département M.O.I.: Rapport Annuel, 1949.

Nº55-03046 Union Minière du Haut-Katanga - Services d’Afrique, Département M.0.I.: Rapport Annuel, 1950.

N656-03049 Union Minière du Haut-Katanga - Services d’Afrique, Département M.O.I.: Rapport Annuel, 1952.

Nº657-03051 Union Minière du Haut-Katanga - Services d’Afrique, Département M.O.I.: Rapport Annuel, 1954.

Nº67-03052 Union Minière du Haut-Katanga - Services d'Afrique, Département M.O.I.: Rapport Annuel, 1955.

№657-03053 Union Minière du Haut-Katanga - Services d’Afrique, Département M.O.I.: Rapport Annuel, 1956.

Nº657-03054 Union Minière du Haut-Katanga - Services d’Afrique, Département M.O.I.: Rapport Annuel, 1957.

Nº58 Union Minère du Haut-Katanga - Services d’Afrique, Département M.O.I.: Rapport Annuel, 1959.

\section{Library of Contemporary History, Royal Museum for Central Africa, Tervuren, Belgium}

Mwana Shaba, no. 13, December 1964.

Mwana Shaba, no. 1, January 1965.

Mwana Shaba, no. 10, October 1965.

Mwana Shaba, no. 123, 15 April 1966.

Mwana Shaba, no. 147, 15 October 1967.

\section{Secondary literature}

Bendel-Larcher, Sylvia. Linguistische Diskursanalyse. Tübingen: Narr, 2015.

Brausch, Georges. Belgian Administration in the Congo. Oxford: Oxford University Press, 1961. Chapelier, Alice. Elisabethville - essai de géographie urbaine. Brussels, 1957. 
Dibwe dia Mwembu, Donatien. Histoire des conditions de vie de travailleurs de l'Union Minière du Haut-Katanga/Gécamines (1910-1999). Lubumbashi: Presses universitaires de Lubumbashi, 2001.

Dibwe dia Mwembu, Donatien. Bana Shaba abandonnés par leur père: Structures de l'autorité et histoire sociale de la famille ouvrière au Katanga (1910-1997). Paris: L'Harmattan, 2001.

Dibwe dia Mwembu, Donatien. "Lubumbashi: histoire et mémoire d'une ville industrielle.” In Villes d'Afrique: explorations en histoire urbaines, edited by Jean-Luc Vellut, 131-144. Paris: L'Harmattan, 2007.

Dibwe dia Mwembu, Donatien. "La Perception du kazi (travail salarié) par les travailleurs de la Gécamines (1910-2010).” In La Société congolaise face à la modernité (1700-2010): mélanges eurafricains offerts à Jean-Luc Vellut, edited by Mathieu Zana Etambala and Pamphile Mabiala Mantuba-Ngoma, 161-176. Paris \& Tervuren: L'Harmattan, 2017.

Éditions du Bureau de l'Information pour Indigènes (INFIND), Service des A.I.M.O. du Gouvernement Général. Á chacun sa maison. Kalina, 1953.

Ergo, André-Bernard. Congo Belge - La colonie assassinée. Paris: L’Harmattan, 2009.

Etzemüller, Thomas. "Social Engineering, Version: 1:0." Docupedia-Zeitgeschichte 7-8 (11.2.2010). https://docupedia.de/zg/Social_engineering?oldid=75535. Accessed November 20, 2018.

Fabian, Johannes. "Kazi: Conceptualizations of Labor in a Charismatic Movement among Swahili-Speaking Workers.” Cahiers d'études africaines 13, no. 50 (1973): 293-325.

Fabian, Johannes. History from Below: The "Vocabulary of Elisabethville" by André Yav, Text, Translations, and Interpretive Essay. Amsterdam \& Philadelphia: John Benjamins, 1990.

Ferrari, Aurélia, Marcel Kalunga, and Georges Mulumbwa. Le Swahili de Lubumbashi. Paris: Karthala, 2014.

Fetter, Bruce. The Creation of Elisabethville, 1910-1940. Stanford: Hoover Institution Press, 1976.

Grévisse, Ferdinand. Le Centre Extra-Coutumier d'Elisabethville: quelques aspects de la politique indigène du Haut-Katanga industriel. Brussels: Institut Royal Colonial Belge, 1951.

Hunt, Nancy Rose. "Domesticity and Colonialism in Belgian Africa: Usumbura's Foyer Social, 1946-1960." Signs: Journal of Women in Culture and Society 15, no. 31 (1990): 447-474.

Hunt, Nancy Rose. A Colonial Lexicon of Birth Ritual, Medicalization, and Mobility in the Congo. Durham, NC: Duke University Press, 1999.

Jäger, Siegfried. Kritische Diskursanalyse: Eine Einführung. Münster: Unrast, 2012.

Lagae, Johan. "In Search of a 'comme chez soi'. The Ideal Colonial House in Congo, 1885-1960." In Itinéraires croisés de la modernité Congo belge, 1920-1950, edited by Jean-Luc Vellut, 239-282. Paris \& Tervuren: L'Harmattan, 2001.

Lagae, Johan. "Modern Living in the Congo: The 1958 Colonial Housing Exhibit and Postwar Domestic Practices in the Belgian Colony." The Journal of Architecture 9, no. 4, (2004): 477-94.

Lagae, Johan. "Towards a Rough Guide for Lubumbashi, Congo. Rethinking "Shared Built Heritage" in a Former Belgian Colony." http://bk.home.tudelft.nl/fileadmin/Faculteit/ BK/Actueel/Symposia_en_congressen/African_Perpectives/Programme/African_ Architectures/doc/APD_wp_5_lagae_paper.pdf. Accessed July 3, 2018.

Lagae, Johan, and Sofie Boonen. "A City Constructed by 'des gens d'ailleurs': Urban Development and Migration Policies in Colonial Lubumbashi, 1910-1930." Comparativ: Zeitschrift für Globalgeschichte und vergleichende Gesellschaftsforschung 25, no. 4 (2015): 51-69. 
Lambertz, Peter. Seekers and Things: Spiritual Movements and Aesthetic Difference in Kinshasa. Oxford and New York: Berghahn, 2018.

Meeuwis, Michael. "Bilingual Inequality: Linguistic Rights and Disenfranchisement in Late Belgian Colonization.” Journal of Pragmatics 43 (2011): 1279-1287.

Ministère des Colonies. Plan décennal pour le Développement économique et social du Congo belge. Brussels: Editions de Visscher, 1949.

Petit, Pierre, and Georges Mulumbwa Mutambwa. “'LA CRISE': Lexicon and the Ethos of the Second Economy in Lubumbashi.” Africa 75, no. 4 (2005): 467-487.

Schicho, Walter. "Diskursanalyse." In Qualitative Methoden in der Entwicklungsforschung, edited by Petra Dannecker, and Birgit Englert, 127-512. Wien: Mandelbaum, 2014.

Seibert, Julia. “'Wind of Change': Worker's Unrest and the Transformation of Colonial Capital in Katanga - Belgian Congo." In Work and Culture in a Globalized World: From Africa to Latin America, edited by Babacar Fall, Ineke Phaf-Rheinberger, and Andreas Eckert, 253-271. Berlin \& Paris: Karthala, 2015.

Seibert, Julia. In die globale Wirtschaft gezwungen: Arbeit und kolonialer Kapitalismus im Kongo (1885-1960). Frankfurt: Campus, 2016.

Swanson, Maynard W. "The Sanitation Syndrome: Bubonic Plague and Urban Native Policy in the Cape Colony, 1900-1909." The Journal of African History 18, no. 3 (1977): 387-410.

Waldburger, Daniela. "Swahili in Eastern Congo: Status, Role and Attitudes." In Pluricentric Languages and Non-Dominant Varieties Worldwide, edited by Rudolf Muhr, 149-163. Frankfurt am Main; Bern; Bruxelles; New York; Oxford; Warszawa; Wien: Peter Lang, 2016. 